\title{
COMMENTARY \\ Protests and possibilities: reframing the agenda for urban secondary schools
}

\section{Stories that change lives}

On a warm evening in May 2018, I sit enthralled as Joan Baez - doyenne of the "protest" song for social justice - performs to a packed audience at London's Albert Hall. One song has a particular contemporary resonance -"Deportee" (Plane Wreck at Los Gatos) - written by the late Woody Guthrie to mark the death of 28 migrant farmers, lost in a plane crash in 1948, while being deported from California back to Mexico. The victims' names were never reported, they were merely "deportees". That song is the inspiration for the word "protest" in the title of this piece. The "possibilities" spring from what comes next. How, as citizens, we give "voice" to those who are not named or heard; and how, as educators, we draw on our personal and collective resolve to change things for the better. In 2017, American writer and poet Tim Z. Hernandez named those Mexican workers gave them back their identities.

The notion of "reframing" the agenda for Urban Secondary Schools comes from the authors contributing to this rich edition of the Journal of Educational Administration who take a scholarly approach to these matters. Nearly three decades ago, Karen Seashore Louis and Matthew Miles (1990) opened up the world of the American urban high school to scrutiny in their seminal book. These well-researched articles offer a window of understanding that provides insights into the sometimes troubling and bewildering - and yet frequently rewarding - world of today's American urban high school. Louis and Miles argued for the need for empowerment and engagement, supported by new forms of school-based leadership and management, themes echoed in the accounts presented in the pages of this journal. However, these articles are located in a very different socio-political environment: a volatile world in which more people are displaced than at any time since the aftermath of the 1939-1945 War: a world on the move, in which half the world's refuges are children (UNHCR, 2015).

There is much to "protest" about when we take stock of young people's lives today in many parts of the world, including the richer nations. Across North America, there are young homeless people swept up in the growing problem of labour and sex trafficking (Murphy, 2017): across the Atlantic in the UK, young people from Vietnam have found themselves trafficked to service cannabis farms (Gentleman, 2017). Despite the high levels of investment in schools (relative to poorer nations), one in five children from socio-economically disadvantaged communities, living in some of the world's most affluent nations, do not feel they belong in school, twice as many as their peers from more advantaged communities (OECD, 2012).

Drawing on their deep knowledge about what is happening in the American urban high school, the contributors to this compendium map out the present-day challenges and problems, and signpost the possibilities: the strategies and approaches that can help reshape school life. Theirs is a powerful imperative which not only speaks to educators in the USA, but also to those elsewhere who seek fresh insights into the nature of schooling in urban localities, and who are committed to reframing the agenda in ways that will enable young people to realise their hopes and their dreams.

Contemporary realities add an urgency to the need to recalibrate what schools do, and how leaders lead. Making sense of those realties, and how the "Zeitgeist" - the ideas

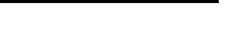


JEA

56,5

and norms that shape society - plays out in our own contexts and impinges on the world of the school, enables us to enter into that process of reframing the agenda for urban secondary schools with greater clarity and focus, as it discussed in the next section.

\section{The changing zeitgeist}

The walls that divide schools from their communities are permeable. Ideas, expectations, assumptions seep through. If there was ever a time that global uncertainties, clashes of culture or belief had little or no impact on children and young people, those days have long since gone.

Changes in the Zeitgeist affect not only adults but also young people. Snippets of news from families and friends combine with the 24 -hour buzz of social media to give youngsters a patchwork of understanding of the world around them. They encode "social tensions" about global conflicts, pick up on "the stress and anger" of the adults around them about contemporary events (Rethinking Schools, 2017, p. 4).

Ebbs and flows in the ever-changing Zeitgeist - the shift in the USA from "Obama" speak to "Trump" speak - alter perceptions and realities, and no more so than in communities with high levels of poverty or social need, or with diverse populations. Schools are communities, "political entities" in which young people learn how to become part of society (Alexander, 2013, p. 3), making an understanding of the Zeitgeist - and the power of the Zeitgeist to change beliefs and expectations - as much the business of schools, as test scores.

Let me illustrate this from a UK perspective.

In July 2012, London launched the opening of the Olympic Games with a sassy ceremony designed by Danny Boyle. His inspiration was Caliban's "isles of wonder" speech in Shakespeare's The Tempest. The three-hour extravaganza, watched by over 1 bn people worldwide, signalled a country apparently at ease with its diversity. The Queen played a cameo role, encountering James Bond. The National Health Service was celebrated. Past "wrongs" were "righted". The ceremony featured an image of the passenger liner "The Empire Windrush", the ship which had brought the first wave of immigrants from the Caribbean to British shores in 1948: invited to help rebuild the nation after the devastation of the 1939-1945 War. The young children who accompanied their parents on that boat, and other boats and planes, came to be known as the "Windrush Generation", and to think of themselves as British.

British-Jamaican Doreen Lawrence (mother of black British teenager Stephen Lawrence, murdered in a racist attack in 1993), helped carry the Olympic Flag. Doreen Lawrence's long fight for justice had come centre stage with the publication of the findings of the Macpherson Inquiry (1999) which identified how institutional racism within the police force had contributed to the white perpetrators going free for many years. Now "Dame" Doreen, she had come to symbolise a new British consciousness about racism.

Fast forward to April 2018, when a scandal of epic proportions erupted, as members of the "Windrush Generation" became unwitting casualties of the UK Government's hard line "hostile environment policy" towards so called "illegal" immigrants. Reaching retirement age in a country in which they thought they belonged, where they had children and grandchildren, where they had lived and worked and paid their taxes, they had become the outsider, the unwanted - the deportee[1].

The full ramifications of the "Windrush" debacle are as yet unknown. However, coupled with a reported increase in hate crimes following Brexit, which led to one newspaper asking: is Britain getting Nastier? (The Big Issue, 2017), they represent a change in the Zeitgeist about what it means to be "British". This raises significant challenges for schools: one of the few shared social institutions that can help create a sense of place and belonging (Riley, 2013). 
Issues about place, belonging and identity are central to the concerns of the authors writing in this journal. As an outsider looking in, I am particularly taken with the contribution they make to our understanding about how we "talk" about deeply important issues which are central to the concerns of urban high school, and are strongly connected to leadership and to the power dynamics of voice and agency. I have divided my reflections about their contribution to our understanding of these matters into three parts:

(1) talking the talk;

(2) leading the walk; and

(3) giving voice and enabling belonging.

\section{Reframing the agenda}

Talking the talk: how do schools talk about important issues, and can they improve on how they do this?

In 1981, I was beginner teacher in a South London inner-city secondary school. A fire at a birthday party, near to the school (The New Cross Fire), took the lives of 13 young black British people aged 14-22. Fire investigators later concluded that the fire had been started deliberately. The Coroner's Court returned an open verdict about the motive. No one has ever been charged. The principal in the school I was working in issued an edict: staff were not to discuss what had happened with their students. This event was beyond the school's jurisdiction and too difficult and complex to engage with.

Yet, the students in my tutor group were part of the story. The clandestine conversations I later had with them revealed their anger and bewilderment. They knew people who had died. They knew people who had been at the party, or had planned to go but had not. The face-to-face conversations I had with senior leaders in that school were never about these challenging issues.

Peter Demerath's engaging article "The emotional ecology of school improvement cultures" which draws on an a long-term ethnographic study of Harrison High School Minnesota unravels some of the complexities about school leaders' "talk". Harrison High is located in a challenging socio-economic context and, over the years, has been applauded for its upward trajectory. Demerath describes what happens when a school culture - crafted through empathy and a commitment to a growth mind-set, and with a leadership team well-versed in the "talk" (the language of emotional engagement) - finds itself at odds with the policy demands of the school district.

The policy in question - which was one of inclusion - was in strong alignment with the school's values. What was antithetical to the staff was the required implementation process. The norms and practices of the staff and their sense of both individual and collective agency - which had been carefully honed over some years - became fractured by the demand to act in ways at variance with their shared beliefs. The case study re-affirms the importance of the collective "talk". When ideas are imposed, there is no discussion about the "how" or the "when", a sense of individual and collective professional agency based on shared values and beliefs is dissipated.

Decoteau Irby and Shannon Clark "Talk it - racism - out" take us into the challenges of talking about race - the practice of "race talk", as they call it. Distinguishing between "race neutral", race proxy' and "race specific" language, they argue that encouraging professional practices which promote race-specific dialogue helps identify points of underlying conflict, increasing the ability of an organisation to analyse issues, and identify potential solutions. The implications of their findings for organisational learning and for leadership are significant which is why - as they point out - we need to understand more about what leaders can do to promote the use of race-specific language, and how they can do this effectively.

Stephanie Marshall and Muhammed Khalifa "Humanising school communities of practice" acknowledge the importance of "race talk" in terms of advocating for "minoritized 
JEA

56,5

458

students", expanding the scope of the discussion by drawing attention to what they describe as "culturally responsive instructional leadership practices". Their research focuses on how instructional coaches - appointed by the school district, as part of a plan to counter educational disparity - prepared for and enacted their role. Their findings contribute to greater understanding of the kinds of leadership behaviours that can help promote "equity consciousness" or "cultural responsiveness" in schools, raising important issues about the agency of school principals.

These contributions reinforce the importance of exploring how school leaders talk, what they talk about and the context in which they are talking - which is why when I read Yi-wah Liou and Peter Daly's article "Broken bridges", I had to re-read one of the summary sentences about their research findings several times:

[...] over time high school principals have decreasing access to social capital and are typically occupying peripheral positions in the social network.

I paraphrased this for myself as follows: the more experienced the six urban high school principals became - in this school district of 25 school principals - the less likely they were to share their learning with their peers (other principals) or be open to new learning. This led me to think about the implications of "not talking". If these high school principals were out of the loop, if they did not "talk" about those challenging and profoundly difficult issues discussed earlier, if they were not thinking about how to develop more culturally responsive leadership behaviours, or exploring how to connect to communities in new ways, or discussing how to respond to the unexpected and traumatic events which can implode so unexpectedly, how did they learn from each other? How did they share what they knew? How could school systems build and share deep knowledge, if the principals of the high schools, or secondary schools did not talk to each other?

These issues play out in the UK in a different - but equally troubling - ways. The current dispensation is one in which local education administrations are increasingly depleted of significant levels of resourcing. The political discourse is about a "self-improving" school system which seeks to maximise individual school autonomy, and encourage schools to collaborate with each other. Results are patchy. At one of the spectrum, a group of system leaders can be found who exercise their leadership beyond their own schools, working to share expertise and practice. At the other end are schools which operate in relative isolation from each other, with their leaders seemingly determined to reinvent the wheel (Earley and Greany, 2017) and reluctant to engage in significant "talk" with their peers.

The degree to which collaboration and knowledge sharing between schools takes places is dependent on the mind-set, opportunities and resources. The mind-set (can we learn from others? Who do we collaborate with?) is shaped by many factors, including structural arrangements. In the UK, schools which are part of Academy chains are expected to collaborate with each other, rather than with local schools. Opportunities to tap into networks and alliances are dependent on professional knowledge and connections, and the degree of access. Resources play their part. In a climate of ongoing reductions in funding for schools, particularly those serving urban communities, school leaders find themselves asking: have we the time and capacity to look beyond the school-gates? Looking to the future, we can expect both greater insularity (individual schools and chains of schools) and deeper forms of collaboration, the latter driven by concerns about increased inequities and the well-being of young people in a highly pressurised system, and supported by a range of institutions, including universities.

\section{Leading the walk: what choices do leaders have about how they lead and how they connect} to communities?

"Talking the talk" is obviously linked to "leading the walk" and implies that school leaders have a degree of agency in what they do and how they do it. The literature on the importance 
of school leaders' sense of agency is well developed (Clarke and Wildy, 2011; Lovett et al., 2015), with new ideas emerging about professional agency (Vahasantanen et al., 2017).

School leaders have choices to make about how they lead and how they exercise their agency. They set the rules of the game. How they think, decide, act and reflect, and draw on their knowledge to create a roadmap of possibilities is critical to the well-being of both children and adults (Riley, 2017).

In policy environments that are driven by output measures, some leaders make choices which can be detrimental to the well-being of particular groups of young people. In the UK, the pressure on schools to perform well on school performance league tables has led to a rise in formal exclusions from school (Gill et al., 2017), with children and young people from low income families being four times more likely to be excluded than their more affluent peers (The Fair Education Alliance, 2017). While this issue is not addressed directly in this issue, it is a critical feature of the context in which urban secondary schools exist.

Researchers from the Centre for High Performance, who studied the changes made by 400 plus UK headteachers from the time of their appointment until they relinquished their leadership role, concluded that the rewards - in terms of money and Honours from the Queen - went to a group the research team designated as "surgeons". Their absolute focus on test results led them to exclude, on average, one in four final-year students and dismiss, or move on, one in ten staff. More effective in the long-term were leaders, designated by the researchers as "architects": who involved parents, got teachers on board, grew their schools and improved teaching. Thus, "leading the walk" in the UK, means just that: do not sprint, take time to talk and to build the shared story.

In a beautifully crafted case study, Ann Ishimara "Re-imaging turnaround" debunks the kinds of super-heroic leadership demonstrated by the "surgeons", criticising its short termism, and its determination to achieve results whatever the cost. Her focus is on the possibilities of a radical change in school-community relationships: what happens when the boundaries and expectations surrounding school-community relationships are tested?

Having read her contribution, I reflected with a sense of relief that the days of schools in diverse multi-cultural communities, organising an Annual Wine and Cheese Evening - and being surprised when relatively few parents turned up - are long since gone, and that there has been significant, if patchy, progress in rethinking the nature of the school-community relationship. Das Gupta (2006), for example, has sought to identify the processes of engagement that can exclude families: a critical issue for refugee families and those who have experienced major dislocations, as Koyama and Rwehumbiza Bakuza (2017) argue. Ishimara's exploration of what happens when school-community relationships are recalibrated in a process of equitable collaboration which builds on the social capital in communities leads us back to the importance of talk. As school and community leaders step together into a more equitable and reciprocal space, the dynamic generated, she argues, transforms the relationship between them. She reinforces the findings from her case study with a powerful conceptual framework for reconceptualising school-community relationships and partnerships: an approach which, as she acknowledges, is all too rare.

Giving voice and enabling belonging: whose voices do we need to hear, and whose do we need to hear if schools are to become places of belonging?

The importance of rethinking the power dynamics and relationships both within school and between schools and communities is critical, as contributors to this journal argue. Some years ago, in "Whose School is it Anyway?" (Riley, 1998), I asked "Who should decide what goes on in schools?" Interviewees for that book included the late British Prime Minister Jim.

Callaghan who took the view that, in the 1970s and 1980s, over-radicalised teachers had ignored the wishes of parents in working-class communities and that teacher domination of the curriculum had to change. Young people's voice was not part of the equation.

Protests and possibilities 
JEA

56,5

To my gratification, two articles in this special issue focus on how can we give "voice" to young people. They also shed light on whose voices decide the things that matter. In a wellhoned and conceptually grounded paper which adds much to the discussion on student voice, Dana Mitra "Student voice in secondary schools" focuses on the role that student voice can play in school reform, identifying the most important outcomes of youth participation in student voice initiatives as being, "Agency, belonging, competence, deliberation and (civic) efficacy". A key finding from research of my own - which involved young people and teachers as co-researchers in a collaborative research injury which asked "Is this school a place where everyone feels that they belong?" - has been the importance of "agency" in generating a sense of belonging (Riley, 2017; Riley et al., 2018) [2]. In a climate that encourages schools, as Dana Mitra describes it, to obey mandates and young people to master facts, her review is a timely reminder of the many ways that young people can be agents of change, and the benefits, not just to them but also to society as a whole.

Rooxbeh Shirazi "Sociopolitical belonging and identities of transnational secondary students" enriches this debate by exploring a complex and contentious issue: the right to belong. Drawing on his research findings, he raises issues about belonging and agency, exploring how the social spaces within a school are experienced by different groups. As other contributors to the journal, he asks tough questions about how school leaders need to think and respond to some of the critical issues, such as: should schools create spaces for "affinity groups to meet?" How and when should they do this? Whose voices are heard and are valued? Whose voices count? While in the UK, there is a growing recognition of the need to listen to what children and young people have to say, there remains a hesitancy to activate their agency, or that of their families.

A sense of belonging in any organisation or institution is shaped by what we bring to it - our histories, our day-to-day lived realities. Young people's sense of belonging or exclusion in school is fashioned by the actualities of school life: relationships and encounters; expectations and beliefs; the pedagogical experiences, as well as the environment for learning; and, of course, the leadership (Riley, 2017; Riley et al., 2018). "Belonging" is that sense of being somewhere where you can be confident that you will fit in and feel safe in your identity (Riley, 2017): a feeling of being at home in a place, and of being valued (Flewitt, 2017). Whether young people are seen for who they are, whether their voices are heard will impact on their sense of agency and of belonging.

\section{To the future}

Joan Baez concluded her performance at the Royal Albert Hall by talking about a new form of protest: the young people across America who - in the wake of ongoing violence-manifested in the High Schools shootings which hit the headlines with unfailing regularity[3] - are exercising their right to protest and in so doing, develop their sense of leadership and agency. Protest shapes possibilities. If young people are to find their way in this troubled world, schools need to be places of possibility and agency. Each contributor to this splendid edition has enriched our understanding of what those possibilities are.

Kathryn Riley Institute of Education, UCL, London, UK

\section{Notes}

1. Up to 63 members of the Windrush Generation have been wrongly deported from the UK and many more threatened with deportation. Others have been refused jobs or denied healthcare (Gentleman, 2018). As of May 2018, upwards of 5,000 cases were being investigated. 
2. Also see www.ucl.ac.uk/ioe-place-and-belonging-in-schools and www.theartofpossibilities.org.uk

3. The increase in knife crime on the streets of London and other urban conurbations has led to a similar response (Lammy, 2018).

\section{References}

Alexander, T. (2013), Citizenship Schools: Learning Democracy, Raising Attainment, Building Community, Cooperative College.

Clarke, S. and Wildy, H. (2011), "Providing professional sustenance for leaders of learning: the glass half-full?", in Townsend, T. and MacBeath, J. (Eds), International Handbook for Leadership in Learning, Springer, Dordrecht, NL, pp. 673-690.

Das Gupta, M. (2006), Unruly Immigrants: Rights, Activism, and Transnational South East Asian politics in the United States, Duke University Press, Durham, NC.

Earley, P. and Greany, T. (2017), "The future of leadership”, in Earley, P. and Greany, T. (Eds), School Leadership and Education System Reform, Bloomsbury, London, pp. 222-228.

Flewitt, R.S. (2017), "Equity and diversity through story: a multimodal perspective", in Cremin, T., Flewitt, R.S., Mardell, B. and Swann, J. (Eds), Storytelling in Early Childhood: Enriching Language, Literacy, and Classroom Culture, Routledge, London and New York, NY, pp. 150-168.

Gentleman, A. (2017), Trafficked and Enslaved: The Teenagers Tending UK Cannabis Farms, The Guardian, London, available at: www.theguardian.com/society/2017/mar/25/traffickedenslaved-teenagers-tendinguk-cannabis-farms-vietnamese (accessed 16 June 2018).

Gentleman, A. (2018), Amelia Gentleman - Official Site, The Guardian, London, available at: www.theguardian.com/profile/ameliagentleman (accessed 16 June 2018).

Gill, K., Quilter-Pinner, H. and Swift, D. (2017), "Making the difference: breaking the link between school exclusion and social exclusion", The Institute for Public Policy Research, London, available at: https/:IPPR/making-the-difference-report-october-2017.pdf (accessed 10 December 2017).

Koyama, J. and Rwehumbiza Bakuza, F. (2017), "A timely opportunity for change: increasing refuge parental involvement in US schools”, Journal of Educational Change, Vol. 18 No. 3, pp. 331-336.

Lammy, D. (2018), "David Lammy pleads for action on knife crime after teenager suffers 'life-changing' injuries”, 'I' News, London, available at: https://inews.co.uk/news/politics/davidlammy-pleadsaction-knife-crime-teenager-suffers-life-changing-injuries/ (accessed 1 May 2018).

Louis, K. S. and Miles, M. (1990), Improving the Urban High School: What Works and Why, Teachers College Press, New York, NY.

Lovett, S., Dempster, N. and Fluckiger, B. (2015), "Personal agency in leadership learning using an Australian heuristic", Professional Development in Education, Vol. 41 No. 1, pp. 127-143.

Macpherson, W. (1999), "The Stephen Lawrence inquiry: report of an inquiry by Sir William Macpherson of Cluny, advised by Tom Cook, the Right Reverend Dr John, Sentamu, Dr Richard Stone, Presented to Parliament by the Secretary of State for the Home Department by Command of Her Majesty”, Cm 4262-I, HMSO, London, February.

Murphy, L. T. (2017), "Labor and sex trafficking among homeless youth", Loyola University, available at: https://covenanthousestudy.org/landing/trafficking/docs/LoyolaResearch-Results.pdf (accessed 1 May 2018).

OECD (2012), Programme for International Assessment (PISA) United Kingdom - Country note - Results from PISA 2012, Organisation for Economic Cooperation and Development, Paris, available at: www.oecd.org/pisa (accessed 1 May 2018).

Rethinking Schools (2017), "Little kids, big ideas, teaching social issues and global conflicts with young children”, Rethinking Schools, Vol. 31 No. 4, pp. 4-5.

Riley, K. (1998), Whose School is it Anyway? Falmer Press, Taylor and Francis, Brighton and London.

Riley, K. (2013), Leadership of Place: Stories from Schools in the US, UK and South Africa, Bloomsbury, London. 
Riley, K. (2017), Place, Belonging and School Leadership: Researching to Make the Difference, Bloomsbury, London.

Riley, K., Coates, M. and Martinez, S.P. (2018), Place and Belonging in Schools: Unlocking Possibilities, UCL Institute of Education, London, available at: www.ucl.ac.uk/ioe/departments-centres/ centres/london-centre-for-leadership-inlearning

The Big Issue (2017), "Big issue foundation”, London, 26 September - 2 October, available at: www. bigissue.com/ (accessed 27 October 2017).

The Fair Education Alliance (2017), "Third state of the nation report card, 2016-2017", The Fair Education Alliance, London, available at: www.faireducation.org.uk/report-card/ (accessed 27 October 2017).

UNHCR (2015), Figures at a Glance, United Nations High Commission for Refugees, Geneva, available at: www.unhcr.org/pages/49c3646c11.html (accessed 10 December 2017).

Vahasantanen, K., Hökkä, P., Paloniemi, S., Herranen, S. and Eteläpelto, A. (2017), "Professional learning and agency in an identity coaching programme", Professional Development in Education, Vol. 43 No. 4, pp. 514-536, available at: https://doi.org/10.1080/19415257.2016.1231131 